\title{
A Study on the Symbolic Significance of Decorative Art of Huizhou Traditional Residential Buildings
}

\author{
Tao Ren \\ College of Urban Planning and Architecture, Southwest Minzu University, Chengdu, China \\ Email: 1104365560@qq.com
}

How to cite this paper: Ren, T. (2021) A Study on the Symbolic Significance of Decorative Art of Huizhou Traditional Residential Buildings. Open Access Library Journal, 8: e7815.

https://doi.org/10.4236/oalib.1107815

Received: July 31, 2021

Accepted: August 20, 2021

Published: August 23, 2021

Copyright ( $) 2021$ by author(s) and Open Access Library Inc.

This work is licensed under the Creative Commons Attribution International License (CC BY 4.0).

http://creativecommons.org/licenses/by/4.0/

(c) (i) Open Access

\begin{abstract}
Chinese traditional architectural decoration has a long history and rich cultural connotation, which is the crystallization of the wisdom of the working people. Architectural decoration is a very important link in the construction of architecture. In Chinese traditional residential houses, architectural decoration carries the cultural phenomenon of folk, folk and all levels of society, and transmits historical information to people. This paper will analyze the cultural connotation of Huizhou residential architectural decoration from the perspective of aesthetic significance and symbolic significance, understand the expression method of symbolic significance, analyze the auspicious patterns of Huizhou architecture, and deeply explore the design implication and aesthetic implication of auspicious patterns in Huizhou architecture. Studying the decorative art of Huizhou residential buildings is helpful to understand the traditional folk culture and art, which reflects the important role of architectural decoration in expressing culture. This paper intends to explore the implied meaning behind the architectural decoration of Huizhou folk houses from the perspective of symbolic significance, analyze and summarize its decoration, and provide reference for the inheritance and development of traditional architectural decoration.
\end{abstract}

\section{Subject Areas}

Architecture

\section{Keywords}

Architectural Decorative Art, Symbolic Meaning, Auspicious Pattern Decoration 


\section{Introduction}

\subsection{Research Background}

Huizhou architecture, also known as Hui-style architecture, is one of the most important schools of Traditional Chinese architecture. As an important part of Hui-style culture, Hui-style architecture has always been respected by architectural masters at home and abroad. Not specifically Anhui architecture, mainly popular in the six counties of Huizhou and most of Yanzhou and the surrounding areas of Hui language. Hui-style buildings share the same characteristics as traditional residential houses in the region. They live together with ethnic groups, facing north and south, and pay attention to internal lighting. Hui-style architecture fully embodies the distinctive local characteristics in the planning of villages and towns, the treatment of plane and space, and the comprehensive application of architectural carving art [1]. In particular, the folk houses, ancestral halls and memorial archways are the most typical, which are praised as the three ancient architectural masterpieces in Huizhou, and are valued and admired by the architectural circles at home and abroad.

Huizhou folk houses are formed in the specific natural and cultural environment. The most distinctive style of Huizhou is a large number of surviving traditional residential villages. From site selection, design, modeling, structure, layout to decoration and beautification, it reflects the mountain features, feng shui wishes and regional beauty trend of Huizhou. Due to the influence of unique geographical environment and cultural environment, it shows distinct regional characteristics in architectural modeling, architectural decoration, architectural structure and other aspects are unique. Among them, the decorative style is the most dazzling and unique. Therefore, the decoration of Huizhou residential buildings not only reflects the functions and aesthetics of the buildings themselves but also embodies the natural scenery and humanistic feelings of Huizhou.

\subsection{Research Significance}

In Huizhou folk houses, the traditional decorative patterns, as decorative symbols, almost run through the entire history of the Chinese nation and are an important part of Chinese traditional culture. In today's society, to make the patterns of the building has been gloriously enrolled cultural value continues, in order to create a deep culture and Chinese characteristics of architectural form. Huizhou residence is a very representative type of architecture, and the study of its decorative art and modeling is helpful for architectural professionals to understand the traditional folk culture and art. Where there is a picture, there is a meaning (Figure 1). I intend to explore the implied meaning behind various architectural decoration, analyze and summarize the decoration, and provide reference for the inheritance and development of traditional architectural decoration [2]. 


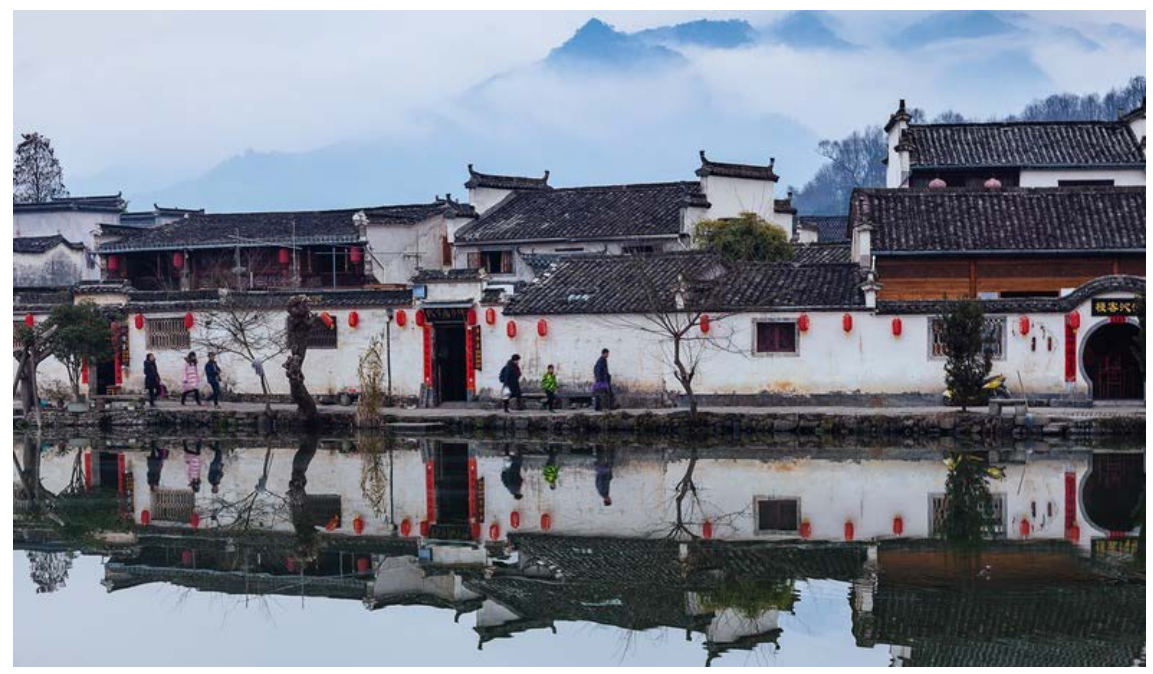

Figure 1. The whole view of Huizhou dwellings. Image source: Internet.

\section{The Architectural Characteristics and Decorative Significance of Huizhou Traditional Residential Houses}

\subsection{Characteristics of Huizhou Residential Buildings and Decorative Arts}

Huizhou style residence is an important school of Traditional Chinese residential architecture. In the forming process, ancient Huizhou architecture was influenced by the unique geographical environment and humanistic concept, showing distinct regional characteristics and having a unique style in many aspects such as shape, function and decoration. Huizhou style residential houses respect the natural landscape environment. Ancient Huizhou took thoughtful consideration of the terrain, landform, water flow and wind direction and other factors in the site selection of villages. They were often near mountains and rivers, with beautiful environment, reasonable layout, smooth traffic and buildings integrated in the landscape. Hui-style architecture, as an important part of Hui-style culture, does not specifically refer to anhui architecture. It is popular in Huizhou, Yanzhou, Jinhua, Quzhou and other areas in western Zhejiang [3]. Wooden beams bearing, brick, stone, earth wall; in the center of the hall, and decorative roof, cornice long. Historically, Hui merchants operated in Yangzhou, Suzhou and other places, and Hui-style architecture also exerted considerable influence on the local architectural style (Figure 2).

The reason why architecture can be called art is that it must have its own unique shape and style. The reason why Huizhou ancient residential buildings are famous at home and abroad is that they become Huizhou style. On the one hand, they retain the integrity, the unity of style, the diversity of modeling and the artistry of form. On the other hand, he has rich historical and cultural connotations. Huizhou people advocate natural beauty and pursue a high degree of harmony and unity between man and nature. This is reflected in Huizhou architecture feng shui beauty. 


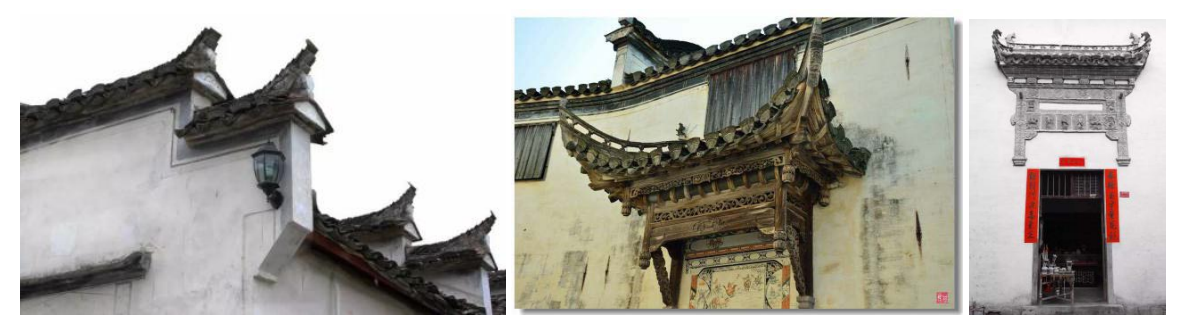

Figure 2. Small department head decoration. Image source: author.

\subsection{Significance of Architectural Decoration of Huizhou Dwellings}

The aesthetic significance of the architectural decoration of Huizhou folk houses firstly lies in any form of decoration of Huizhou folk houses, which is not originated from beauty for beauty's sake. 1) Art deco and architectural structure are integrated to complement each other. Such as door head brick carving, capital, poplar wood carving, and then as a decorative object; 2) From the practical application, such as the door, window, lattice fan used by the fine lattice. There was no glass at that time, and in order to keep out the wind and light, it was necessary to paste vellum over the doors and Windows. When the panes were too large, the vellum was vulnerable, so they were all in fine plaid, and this fine plaid pattern was formed afterwards; On the high walls of Huizhou residential buildings, if there is Hui head carving and roof ridge brick carving, it cannot achieve the effect of viewing, so the brick carving is not developed, generally only in the door head brick tile eaves slightly ridge carving tile decoration. Wall brick carving is widely used in the central Plains, Suzhou, Leshan and other places in the folk houses, but in Huizhou, it has become a tool to prevent evil in feng shui.

\section{Symbolic Expression}

As a kind of cultural form, Huizhou folk houses are endowed with the meaning of "culture" and express people's needs, values, desires and emotions through images, space, environment and sequence. Among many means of expression, it is an important means of artistic expression to make buildings have a certain meaning by means of imitation, association and similarity, and the manifestation of this meaning in architecture is mainly realized by decorative means such as light, shade, color, texture and pattern.

Huizhou residential decoration, its content and form rich and colorful, but on the whole, have distinctive features, is to make these decorative pattern contains distinct meaning, but also make full use of the symbol of Chinese traditional art, metaphors, local aesthetic consciousness and ideas organically, intuitive reflects clearly the meaning and purpose. For example, out of the superstition of color, to pray for peace by symbolic means, because water can fight fire, with the representative of water green as the main color of wood paint (Figure 3).

Architectural decoration meets the needs of people's spiritual activities, such as psychological, ethical, religious, aesthetic and so on. It expresses the designer, the builder and the user's thought emotion, the life condition, the concept form, 


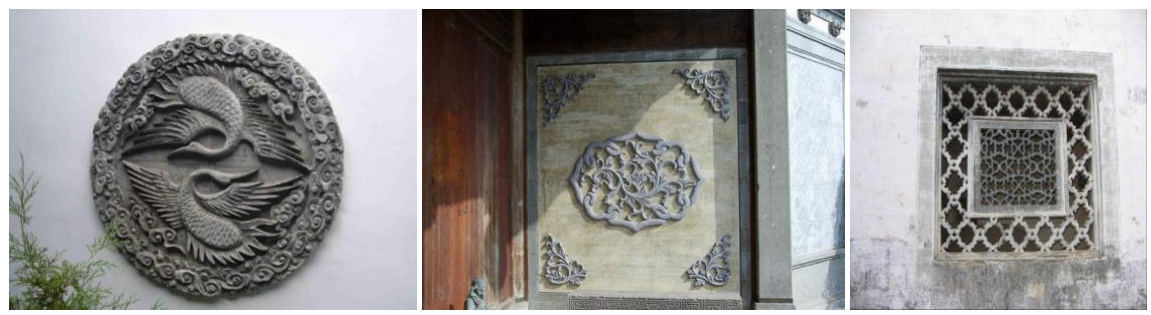

Figure 3. Decoration pattern. Image source: Internet.

the life philosophy and the aesthetic taste and so on. "The meaning of traditional design language is to inspire and develop modern thinking". Studying the decorative art of Huizhou residential buildings is helpful to understand the traditional folk culture and art, and to deeply understand the important role of architectural decoration in the expression of culture, so as to draw beneficial nutrition and integrate ancient and modern culture into modern architecture.

\section{Auspicious Patterns of Huizhou School Architecture}

\subsection{Analysis of Auspicious Patterns of Huizhou Architecture}

Hui-style architecture is important school of Traditional Chinese architecture, and auspicious patterns are one of its artistic features. The auspicious decorative patterns in Hui-style architecture are in line with traditional Chinese thought and have profound cultural connotations and aesthetic implications.

The auspicious patterns of Hui-style architecture play a pivotal role in the decorative arts of the Chinese nation. They combine the knowledge of history, culture, philosophy, art and other disciplines, and are expressed through wood carving, brick carving, stone carving and color painting. The auspicious patterns of Hui-style architecture are rich in theme and variety. From the perspective of decoration intention, the auspicious patterns of Hui-style architecture can be divided into plant patterns, animal patterns, landscape patterns, character story patterns, geometric patterns and so on.

\subsection{Design Implications of Huizhou Architectural Auspicious Patterns}

The auspicious patterns of Hui-style architecture are handed down from generation to generation according to the living customs and auspicious concepts of Huizhou people. In the rich and diverse auspicious patterns, we can appreciate the unique design concept of Huizhou people.

\subsubsection{Unity of Form and Content}

The auspicious patterns of Hui-style architectural decorative art embody the principle of unity of form and content. The auspicious patterns of Hui-style architecture cleverly use figures, flowers, birds, animals, the sun, the moon and stars, myths and legends, historical events and folk proverbs as themes, and through homophonic, metonymy, puns, symbols and other expressive techniques, to create a perfect combination of graphics and auspicious meaning of 
art form [4]. Ancient Huizhou people are good at incorporating the auspicious concept into some things or phenomena and expressing people's inner wishes through the similar pronunciation of characters. Hui-style architecture is also good at expressing specific auspicious meanings through specific graphics and borrowing objects to convey meanings.

\subsubsection{Combination of Representational and Abstract}

The auspicious patterns of Hui-style architecture use concrete figures and abstract figures. In Hui-style architecture, ancient Huizhou people endowed some concrete or abstract symbols with certain symbolic meanings. The symbolic meanings of these special symbols were transmitted among people and gradually solidified in individual consciousness and collective consciousness, thus gaining recognition from more and more people. For example, the rabbit represented the moon in the sky in the ancient Huizhou people's ideology. Fish patterns indicate abundance. Some of the auspicious patterns of Hui-style architecture are specific and vivid, while others are abstract and concise.

\subsubsection{The Longing of Beautiful Artistic Conception}

The auspicious patterns in Hui-style architecture advocate romance and beauty. So the wisdom of the ancient Ancient Huizhou people gradually broke the thoughts for the natural object in the ideas of bondage, make all the good things cleverly reflected in building decoration pattern, such as phoenix grain, Xiangyun grain, fish, plants, lines and so on pattern image can be seen everywhere, in the building has been gloriously enrolled on the Ancient Huizhou people longing and yearning for a better life. The auspicious patterns in Hui-style architecture advocate romance and beauty. So the wisdom of the ancient Ancient Huizhou people gradually broke the thoughts for the natural object in the ideas of bondage, make all the good things cleverly reflected in building decoration pattern, such as phoenix grain, Xiangyun grain, fish, plants, lines and so on pattern image can be seen everywhere, in the building has been gloriously enrolled on the Ancient Huizhou people longing and yearning for a better life.

\section{Conclusion}

In the process of the continuous development of culture, symbols have rich and colorful symbolic meanings, that is the rich connotation of cohesion. Symbols are no longer simple symbols with associative meanings. In the process of continuous development, we can now determine the symbolic symbols that can carry these meanings according to some specific meanings, from the former passive meaning to the current active meaning. The perspective of symbolic meaning of symbols to mobilize people thinking and affect our emotions, construction as a part of human culture, is also a kind of visual symbol system; we can also through the visual perception building symbols to express specific information to us, so we can through the symbolic symbols understanding to these buildings expressed by some kind of significance. This has great enlightenment to the research of 
minority architecture in the future. Traditional Chinese architecture is deeply influenced by cultural regions and other aspects, and architectural symbols also express a variety of symbolic meanings. As a part of traditional Chinese architecture, the Jiarong Tibetan resident architecture in $\mathrm{Xi}$ so village has continuously improved and absorbed the cultural concepts of other Tibetan areas during its long-term formation and evolution. It forms the unique symbolic architectural symbol and unique traditional culture and folk customs of Jiarong Tibetan residential buildings. Through this study, the symbolic significance of architectural symbols of most of the Xi zuo residential houses is summarized, and it can be applied to the later Jiarong Tibetan architecture by adding it.

\section{Conflicts of Interest}

The author declares no conflicts of interest.

\section{References}

[1] Li W. and Zheng, X. (2014) A Study on the Architectural Decoration characteristics of Huizhou Dwellings in Ming and Qing Dynasties. Jilin Jianzhu University, Changchun, Jilin.

[2] Xin, F.S. (2012) Study on the Basic Characteristics and Gene Recognition of Huizhou Traditional Village Landscape. Anhui Normal University, Wuhu City, Anhui.

[3] Zhang, N. and Zhang, Y. (2021) Design Aesthetics Analysis of Hui-style Architecture. College of Art and Design, Nanjing Forestry University, Nanjing.

[4] Zhang, L. (2013) The Application of Huizhou Residential Building Decoration Yuanjing in Modern Timber Structure Building. Beijing Forestry Character, Beijing. 